\title{
U.S. International Transactions in 1999
}

Francis E. Warnock, of the Board's Division of International Finance, prepared this article. Nancy E. Baer provided research assistance.

The U.S. current account deficit increased substantially in 1999 as the balances on goods and services, investment income, and unilateral transfers all became more negative. The remarkable strength of the U.S. economy contributed significantly to a marked decrease in the balance on goods and services; to a lesser extent, previous declines in U.S. price competitiveness also played a role. The balance on investment income decreased because of the additional net income payments on the growing U.S. external indebtedness.

Most of the widening of the current account deficit in 1999 was due to the large and growing gap between U.S. imports and U.S. exports of goods (table 1). Exports increased as foreign economies rebounded sharply after a weak performance in 1998, but imports increased even more, primarily because of the greater strength of the U.S. economy. The dollar did not strengthen further in 1999, but the continued effect of its sharp appreciation in 1997 and 1998 increased imports and reduced exports. A reduced surplus in trade of services and an increased deficit in unilateral transfers added to the growth of the deficit. The balance on investment income- which moved into deficit in 1998 for the first time since 1914-became even more negative, mainly because of a large decline in net portfolio income.

The current account deficit reached 3.7 percent of U.S. gross domestic product (GDP) last year, surpassing the previous record set in 1987. This deficit and the continued U.S. investment abroad were more than financed by huge foreign acquisitions of U.S. assets. A record amount of private foreign investment poured into the United States; moreover, substantial foreign official inflows resumed after the Asian and Russian financial crises of 1997 and 1998.

\section{MAJOR ECONOMIC INFLUENCES ON U.S. INTERNATIONAL TRANSACTIONS}

Several factors shaped the U.S. current and financial accounts in 1999. ${ }^{1}$ The most important of these were

1. To conform with international conventions, U.S. international transactions are now presented in three groups-a current account, a capital account, and a financial account. Previously, transactions were presented in two groups - a current account and a capital account. The new financial account is the same as the previous capital account. The new capital account consists of a small part of unilateral transfers that were previously in the current account. More details may be found in Christopher L. Bach, "U.S. International Transactions, Revised Estimates for 1982-98," Survey of Current Business, vol. 79 (July 1999), pp. $60-72$.

1. U.S. international transactions, 1995-99

Billions of dollars except as noted

\begin{tabular}{|c|c|c|c|c|c|c|}
\hline Item & 1995 & 1996 & 1997 & 1998 & 1999 & $\begin{array}{l}\text { Change, } \\
1998 \text { to } 1999\end{array}$ \\
\hline $\begin{array}{l}\text { Trade in goods and services, net } \\
\text { Goods, net } \ldots \ldots \ldots \ldots \ldots \ldots \ldots \\
\text { Services, net } \ldots \ldots \ldots \ldots \ldots \ldots \ldots\end{array}$ & $\begin{array}{r}-98 \\
-174 \\
76\end{array}$ & $\begin{array}{r}-104 \\
-191 \\
87\end{array}$ & $\begin{array}{r}-105 \\
-197 \\
92\end{array}$ & $\begin{array}{r}-164 \\
-247 \\
83\end{array}$ & $\begin{array}{r}-268 \\
-347 \\
80\end{array}$ & $\begin{array}{r}-103 \\
-100 \\
-3\end{array}$ \\
\hline $\begin{array}{l}\text { Investment income, net ....... } \\
\text { Unilateral current transfers, net }\end{array}$ & $\begin{array}{r}24 \\
-35\end{array}$ & $\begin{array}{r}22 \\
-42\end{array}$ & $\begin{array}{r}8 \\
-42\end{array}$ & $\begin{array}{r}-7 \\
-44\end{array}$ & $\begin{array}{l}-19 \\
-47\end{array}$ & $\begin{array}{r}-12 \\
-3\end{array}$ \\
\hline Current account balance . & -114 & -129 & -143 & -221 & -339 & -118 \\
\hline $\begin{array}{l}\text { Official capital, net } \ldots \ldots \ldots \\
\text { Private capital, net } \ldots \ldots \ldots\end{array}$ & $\begin{array}{l}99 \\
38\end{array}$ & $\begin{array}{r}133 \\
61\end{array}$ & $\begin{array}{r}17 \\
269\end{array}$ & $\begin{array}{r}-29 \\
239\end{array}$ & $\begin{array}{r}53 \\
325\end{array}$ & $\begin{array}{l}82 \\
87\end{array}$ \\
\hline Financial account balance & 137 & 194 & 286 & 210 & 378 & 168 \\
\hline Capital account balance & $\mathbf{0}$ & 1 & $\mathbf{0}$ & 1 & $\mathbf{0}$ & -1 \\
\hline Statistical discrepancy & -24 & -65 & -143 & 10 & -39 & -49 \\
\hline $\begin{array}{l}\text { MEMo } \\
\text { Current account as percentage of GDP }\end{array}$ & -1.5 & -1.7 & -1.7 & -2.5 & -3.7 & \\
\hline
\end{tabular}

Note. In this and the tables that follow, components may not sum to totals because of rounding.

SourCE. U.S. Department of Commerce, Bureau of Economic Analysis, U.S. international transactions accounts. 
the recovery of foreign economic activity after the crises of 1997 and 1998, a rebound in the prices of primary commodities, the continued strong performance of the U.S. economy, and the lingering effects of a strong dollar on the price competitiveness of U.S. goods.

\section{Foreign Economic Activity}

After a year and a half of financial crises and depressed growth, foreign economies rebounded remarkably quickly in 1999. Foreign economic growth, at a robust 4.3 percent on average for the year, showed a sharp improvement over the 0.8 percent growth in 1998 (table 2). In 1999, the pace of activity increased in developing countries, with Asian emerging-market economies in particular bouncing back strongly from output declines of the previous year. Activity also recovered in Latin America, with especially strong growth in Mexico but a more mixed performance in other countries. Real growth improved in all of the major industrial countries as well. Growth in Canada was particularly strong. Economic activity in Japan remained weak but was stronger than in 1998.

The year started with concerns that the financial crises of 1997 and 1998 would continue to spread. With the effects of the August 1998 collapse of the ruble and the default on Russian government debt still reverberating, Brazil experienced pressure on its currency, the real, and abandoned its currency peg in January. Once allowed to float, the real soon fell nearly 50 percent against the dollar, generating fears of a depreciation-inflation spiral that could return Brazil to its high-inflation past and renewing financial strains in other Latin American economies. By spring, the Brazilian central bank's commitment to fighting inflation led to sharply higher interest rates and buoyed investor confidence. In time, financial markets stabilized in the region, but the combination of high interest rates and diminished access to international capital markets tended to damp economic activity in much of Latin America. An exception was Mexico, where economic activity, raised by strong growth of exports to the United States and rising oil prices, increased more than 5 percent for the year.

The recovery of activity last year was sharper and more widespread in Asian developing countries than in Latin America, just as the downturn had been the previous year. A combination of accommodative monetary policies, a shift toward fiscal stimulus, and an ongoing boost to net exports provided by previous sharp currency depreciations and the boom in the global electronics market spurred economic growth. Korea's recovery was the most robust, with growth of 14 percent in 1999 after a decline of 6 percent the previous year. However, significant weaknesses remained in Asia, as evidenced by the recent near collapse of Daewoo, Korea's second largest conglomerate, and by continuing problems in financial sectors.

2. Change in real GDP in the United States and abroad, 1996-99

Percentage change, annual rate

\begin{tabular}{|c|c|c|c|c|c|c|c|c|c|}
\hline \multirow{2}{*}{ Country } & \multirow{2}{*}{1996} & \multirow{2}{*}{1997} & \multirow{2}{*}{1998} & \multirow{2}{*}{1999} & \multicolumn{5}{|c|}{ Half years } \\
\hline & & & & & 1997:H2 & 1998:H1 & 1998:H2 & 1999:H1 & 1999:H2 \\
\hline United States & 4.1 & 4.1 & 4.7 & 4.6 & 3.4 & 4.5 & 4.9 & 2.8 & 6.5 \\
\hline Total foreign ${ }^{1}$ & 4.3 & 4.1 & .8 & 4.3 & 3.6 & .4 & 1.2 & 4.5 & 4.2 \\
\hline Asian emerging markets ${ }^{2}$ & 7.0 & 4.7 & -1.9 & 8.2 & 2.3 & -6.1 & 2.4 & 9.2 & 7.3 \\
\hline Thailand $\ldots . . . . . . .$. & 3.8 & -5.1 & -7.2 & 6.8 & -10.4 & -16.2 & 2.9 & 3.2 & 10.6 \\
\hline Korea ... & 6.8 & 3.7 & -5.5 & 14.0 & .7 & -15.8 & 6.1 & 15.2 & 12.8 \\
\hline Malaysia & 9.6 & 5.7 & -10.3 & 10.6 & 3.2 & -12.8 & -7.7 & 17.5 & 4.1 \\
\hline Indonesia . & 10.2 & 1.1 & -17.7 & 6.0 & 3.2 & -29.3 & -4.2 & 11.5 & .8 \\
\hline Hong Kong & 5.5 & 2.2 & -5.8 & 8.6 & -2.4 & -8.1 & -3.4 & 5.7 & 11.7 \\
\hline China ....... & 9.2 & 8.2 & 9.5 & 6.2 & 6.9 & 6.7 & 12.4 & 1.7 & 11.0 \\
\hline Latin America ${ }^{3}$ & 6.3 & 6.1 & 1.0 & 3.7 & 6.2 & 3.3 & -1.3 & 2.8 & 4.6 \\
\hline Mexico ....... & 7.1 & 6.7 & 2.6 & 5.2 & 6.8 & 4.0 & 1.3 & 5.0 & 5.5 \\
\hline Brazil . & 5.5 & 2.2 & -1.6 & 3.2 & 1.9 & 2.4 & -5.4 & 3.6 & 2.9 \\
\hline Argentina & 9.3 & 7.8 & -.6 & .1 & 8.0 & 5.4 & -6.3 & -3.5 & 3.8 \\
\hline Venezuela & .6 & 6.7 & -5.0 & -4.6 & 2.8 & .6 & -10.2 & -7.7 & -1.3 \\
\hline Japan & 5.2 & -.5 & -3.1 & .0 & 6 & -2.7 & -3.4 & 5.1 & -4.7 \\
\hline Canada & 2.4 & 4.4 & 2.8 & 4.7 & 4.5 & 1.9 & 3.7 & 4.3 & 5.0 \\
\hline Western Europe & 2.2 & 3.6 & 1.7 & 3.2 & 3.5 & 2.4 & 1.1 & 2.8 & 3.5 \\
\hline
\end{tabular}

NotE. Aggregate measures are weighted by moving bilateral shares in U.S. exports of nonagricultural merchandise. Annual data are four-quarter changes. Half-yearly data are calculated as Q4/Q2 or Q2/Q4 changes at an annual rate. 1. Selected regions and countries are shown below.

2. Weighted average of China, Hong Kong, Indonesia, Korea, Malaysia, Philippines, Singapore, Taiwan, and Thailand.

3. Weighted average of Mexico, Argentina, Brazil, Chile, Colombia, and Venezuela.

SOURCE. Various national sources. 
Economic activity accelerated in nearly all of the major industrial countries. In Europe, the process was aided by decreases in official interest rates early in the year and by the global recovery, which stimulated external demand. In Canada, real growth rose sharply, as strong external demand from the United States and a recovery in commodity prices contributed to large income and employment gains. After two consecutive years of decline, Japanese real GDP was flat; fiscal stimulus in the first half of the year supported growth, but private consumption remained weak.

\section{Prices of Primary Commodities}

After falling sharply in 1997 and 1998, prices of primary commodities firmed in 1999 in response to stronger demand and reduced supply. Primary commodity prices, which helped mute consumer price inflation in the United States while they fell in 1997 and 1998, began to put upward pressure on U.S. prices in 1999.

\section{Oil Prices}

The precipitous decline in the price of oil in 1997 and 1998 - caused by weak global economic activity and a strong increase in oil production-was more than fully reversed in 1999. The average spot price for West Texas intermediate, the U.S. benchmark crude, rose steadily to reach $\$ 25$ per barrel by the end of the year (chart 1). Strengthened world demand and constrained world supply drove the rebound in oil prices. Not surprisingly, the strong U.S. economy, combined with a recovery of economic activity abroad, led to an increase of 1 percent in world oil consumption.

1. Oil prices, 1985-99

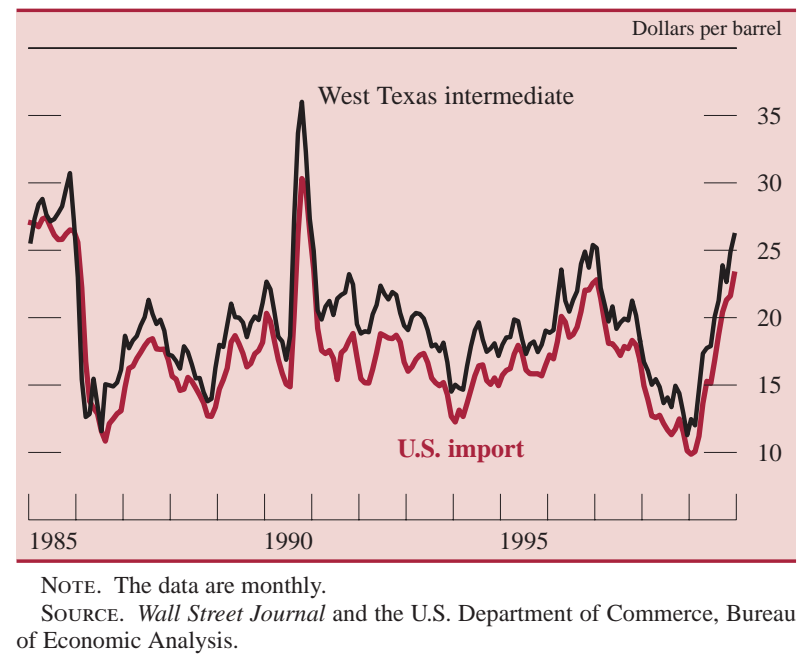

Perhaps more surprising was the 2 percent decline in world oil production, attributable primarily to the reduction in supply from the Organization of Petroleum Exporting Countries (OPEC) and other key producers. In March 1999, OPEC agreed to reduce crude oil production; non-OPEC Mexico, Russia, Oman, and Norway also pledged reductions. The consistently high level of compliance with the March accord stands in contrast to the widespread noncompliance that characterized earlier agreements. A new, pro-OPEC political administration in Venezuela and increased cooperation between Iran and Saudi Arabia helped maintain the agreement.

\section{Prices of Non-Oil Primary Commodities}

After falling about 20 percent over the previous two years, prices of world primary commodities other than oil appeared to bottom out in 1999 (chart 2). From the end of 1997 through 1998, weak global demand, combined with a large increase in supply in response to the high prices of the mid-1990s (especially for agricultural commodities such as grains, oilseeds, and coffee), put severe pressure on commodity prices. Prices fell 5 percent more in the first half of 1999, but reduced supplies and the recovery in global economic activity reversed this decline in the second half of the year, and prices ended the year about where they began.

\section{U.S. Economic Activity}

U.S. economic performance remained extraordinary in 1999, as the rise in real GDP exceeded 4 percent

2. Prices of world non-oil primary commodities, 1985-99

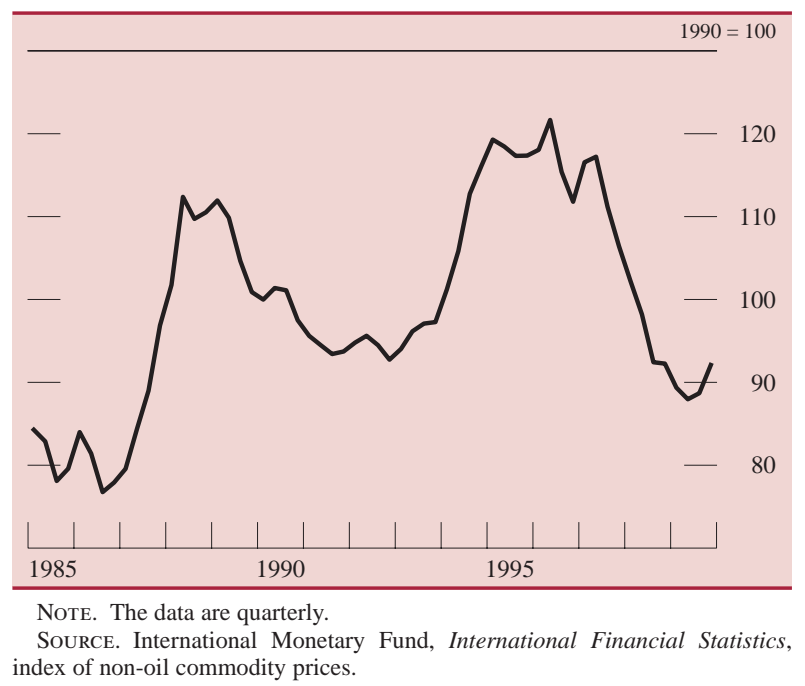


for the fourth year in a row (table 2). Growth in household expenditures, which was exceptionally rapid for the second straight year, was bolstered by further substantial gains in real income, favorable borrowing conditions, and a rising stock market. Seeking to maintain their competitiveness and profitability, businesses continued to invest heavily in hightech equipment. The annual increase in government spending, on both investment and consumption, was the largest of the current expansion. In all, domestic demand continued to surge ahead faster than domestic production, even as the latter was being boosted by strong gains in productivity; the result was a large trade deficit. The gains in productivity, along with considerable though shrinking slack in economies abroad, helped contain inflation despite strong domestic demand and tight labor markets.

A key element in the vigorous expansion has been the boom in capital investment by the private sector. Looking at the sources of financing for this investment offers one perspective on the U.S. trade and current account deficits. As an accounting identity, investment must be financed out of a combination of national savings and savings from abroad. National savings consist of private savings and government savings. Government savings are the opposite of the fiscal deficit, whereas private savings consist of both household savings (that part of after-tax income not spent on consumption) and corporate savings (broadly, retained earnings). Savings from abroad are net foreign investment in the United States, which corresponds to the current account deficit less net exports of gold and certain other transactions.

Chart 3 shows the role that foreign savings has played in financing investment in the United States.

3. U.S. investment, savings, and current account balance as a percentage of GDP, 1980-99

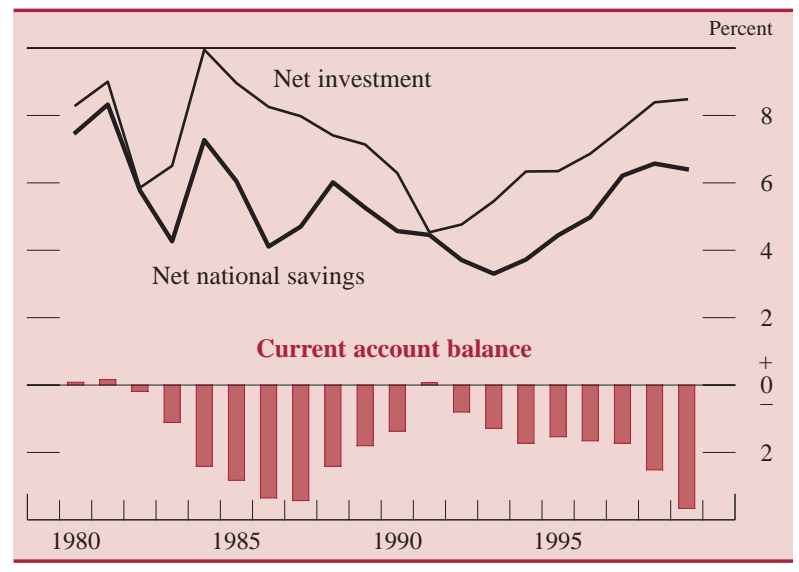

SouRCE. U.S. Department of Commerce, Bureau of Economic Analysis, national income and product accounts, and U.S. international transaction accounts.
In the mid-1980s, the strong increase in foreign savings cushioned U.S. investment from the full impact of a sharp fall in national savings. In the late 1980s, foreign savings dropped as investment fell more quickly than national savings. In the early part of the current expansion, national savings increased, as the swing from the large budgetary deficits of the early 1990s to the budget surpluses of recent years enabled the increase in government savings to outpace the fall in private savings. However, in the past two years, national savings have leveled off: Private savings have continued to fall, and an increase in government spending has slowed the increase in government savings. As in the mid-1980s, this leveling-off has not dragged down investment because the decline in national savings has been offset by an increase in foreign savings - that is, U.S. investment prospects have attracted huge capital inflows.

\section{Exchange Value of the Dollar}

The dollar's exchange value, measured on a tradeweighted basis against a broad range of trading partners, rose about 6 percent in the first half of the year and then fell a like amount to end the year about unchanged (chart 4). On the heels of its sharp appreciation over the previous few years, which reflected the financial crises that afflicted many developing countries, the dollar remains at a high level.

Though over the year the dollar's aggregate value was little changed, its movements against two major currencies diverged. For the second straight year, the dollar depreciated 10 percent against the Japanese yen. The yen's appreciation in 1999 coincided with a hint of economic recovery in Japan and reports of large inflows of foreign capital into the Japanese stock market, and it prompted official foreign exchange intervention from the Japanese authorities. Against the euro, which came into operation at the start of the year, the dollar appreciated sharply, 16 percent on balance. ${ }^{2}$ Early in the year, the euro's depreciation against the dollar was attributed to slow economic growth in the euro area. Its further depreciation later in the year, when growth picked up, was attributed in part to concerns about the prospective relative returns on euro-area investment, given the disappointing pace of market-oriented structural reforms in the area, as well as surprisingly strong growth in the United States.

2. For more information about the euro, see Carol C. Bertaut and Murat F. Iyigun, "The Launch of the Euro," Federal Reserve Bulletin, vol. 85 (October 1999), pp. 655-66. 
4. Foreign exchange value of the U.S. dollar, 1996-99

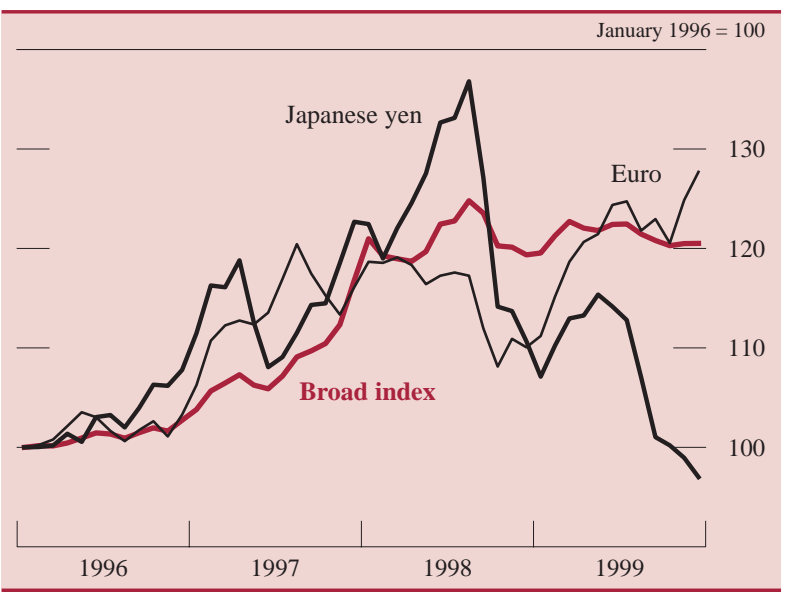

Note. The broad index included thirty-five currencies until the beginning of stage three of European Economic and Monetary Union on January 1, 1999, when the euro replaced the ten euro-area currencies; the broad index now has twenty-six currencies. Currencies of all foreign countries or regions that had a share of U.S. non-oil imports or nonagricultural exports of at least $1 / 2$ percent in 1997 are included in the broad index. The data for the euro use the restated German mark before January 1999. The data are monthly.

The dollar fell slightly against the Mexican peso and the Canadian dollar, the currencies of two important U.S. trading partners, and rose markedly against South American currencies, mainly because of the sharp depreciation of the Brazilian real in early 1999. The dollar's value against currencies of Asian emerging-market economies was on average steady, but it remains at a high level after the jump that coincided with the large depreciations of those currencies in 1997.

\section{DEVELOPMENTS IN U.S. TRADE IN GOODS AND SERVICES}

The overall U.S. trade deficit was substantially larger in 1999 than in 1998 (table 3). The nominal trade deficit for goods and services increased $\$ 103$ billion, to $\$ 268$ billion, in 1999 , as exports expanded less rapidly than imports. Although strong GDP growth inkey foreign markets boosted the demand for U.S. goods, the decline in price competitiveness of U.S. goods in 1997 and 1998 continued to damp the growth of exports. The strong growth of imports in 1999 reflected the strength of U.S. economic activity and the past real appreciation of the dollar, which made imports inexpensive relative to domestic goods. Relatively inexpensive imports, coupled with the growing trade deficit, led to worsening trade tensions but to no substantial shift in U.S. trade policy.

3. U.S. international trade in goods and services, 1996-99

Billions of dollars except as noted

\begin{tabular}{|c|c|c|c|c|c|c|}
\hline Item & 1996 & 1997 & 1998 & 1999 & $\begin{array}{c}\text { Dollar } \\
\text { change, } \\
1998 \text { to } 1999\end{array}$ & $\begin{array}{c}\text { Percentage } \\
\text { change, } \\
1998 \text { to } 1999\end{array}$ \\
\hline Balance on goods and services & -104 & -105 & -164 & -268 & -103 & . \\
\hline Exports of goods and services & 850 & 939 & 934 & 960 & 26 & 2.8 \\
\hline Services & 238 & 259 & 264 & 277 & 13 & 5.1 \\
\hline Goods . & 612 & 680 & 670 & 683 & 13 & 1.9 \\
\hline Agricultural products & 61 & 58 & 53 & 49 & -4 & -6.9 \\
\hline Nonagricultural goods & 551 & 621 & 617 & 634 & 16 & 2.7 \\
\hline Capital goods & 253 & 296 & 300 & 311 & 10 & 3.5 \\
\hline Aircraft and parts & 31 & 41 & 54 & 53 & -1 & -1.1 \\
\hline Computers, peripherals, and parts . & 44 & 49 & 45 & 47 & 1 & 2.9 \\
\hline Semiconductors $\ldots \ldots \ldots \ldots \ldots \ldots$ & 36 & 39 & 38 & 47 & 9 & 24.5 \\
\hline Other machinery and equipment .... & 143 & 166 & 164 & 164 & 0 & .3 \\
\hline Industrial supplies $\ldots \ldots \ldots \ldots \ldots \ldots$ & 138 & 148 & 138 & 139 & 1 & .5 \\
\hline Automotive products & 65 & 74 & 73 & 75 & 2 & 2.1 \\
\hline Consumer goods ..... & 70 & 77 & 79 & 81 & 1 & 1.7 \\
\hline Other nonagricultural exports & 25 & 27 & 26 & 29 & 3 & 11.5 \\
\hline Imports of goods and services & 954 & 1,043 & 1,098 & 1,228 & 130 & 11.8 \\
\hline Services $\ldots \ldots \ldots \ldots \ldots$ & 151 & 167 & 181 & 197 & 16 & 9.1 \\
\hline Goods.$\ldots \ldots \ldots \ldots \ldots \ldots$ & 803 & 876 & 917 & 1,030 & 113 & 12.3 \\
\hline Oil ... & 73 & 72 & 51 & 68 & 17 & 33.1 \\
\hline Non-oil goods & 731 & 805 & 866 & 962 & 96 & 11.1 \\
\hline Capital goods & 228 & 253 & 270 & 297 & 27 & 10.1 \\
\hline Aircraft and parts & 13 & 17 & 22 & 23 & 2 & 7.1 \\
\hline Computers, peripherals, and parts .. & 62 & 70 & 72 & 81 & 9 & 12.4 \\
\hline Semiconductors ..................... & 37 & 37 & 33 & 38 & 4 & 12.6 \\
\hline Other machinery and equipment .... & 117 & 130 & 142 & 154 & 13 & 8.9 \\
\hline Industrial supplies & 137 & 146 & 152 & 157 & 4 & 2.9 \\
\hline Automotive products . ............. & 129 & 140 & 149 & 180 & 30 & 20.4 \\
\hline Consumer goods & 172 & 194 & 217 & 240 & 23 & 10.7 \\
\hline Food and other goods & 65 & 72 & 79 & 90 & 11 & 13.8 \\
\hline
\end{tabular}




\section{Proximate Determinants of Trade in Goods and Services}

The savings-investment balance, discussed earlier, provides useful insights for understanding current account imbalances. However, as an accounting identity, it does not explain the forces that are driving the current account deficit. It is useful, therefore, to look at the proximate determinants of trade flows: U.S. GDP growth, foreign GDP growth, and the price competitiveness of U.S. goods (see box).

There are close historical associations between U.S. real imports and U.S. real GDP and between U.S. real exports and foreign real GDP, as well as between the price competitiveness of U.S. goods and the overall trade deficit (chart 5). ${ }^{3}$ As growth in U.S. real GDP slowed late in the previous expansion, so did growth in U.S. imports (chart 5, top panel). In the current expansion, growth of U.S. imports has picked up. Similarly, U.S. export growth has broadly mirrored foreign real GDP growth. U.S. export growth—strong

3. In each panel of chart 5, the variable represented by the black line is a key proximate determinant of the variable represented by the red line. in the late 1980s, when foreign economic activity was particularly robust-slowed considerably along with world economic growth in the early 1990s (chart 5, middle panel). Export growth rebounded in the mid-1990s before succumbing to the global economic slowdown of 1997 and 1998. In 1999, U.S. export growth increased, but by less than might have been expected if one looked only at the strong recovery in foreign economic activity.

The price competitiveness of U.S. goods helps explain why U.S. export growth staged only a weak recovery in 1999. When prices of U.S. goods increase relative to the U.S. dollar price of foreign goods, the trade deficit tends to increase, albeit with a lag, because U.S. residents tend to increase their purchases of the relatively less expensive foreign goods while foreigners cut back their purchases of the relatively expensive U.S. goods. The large trade deficits of the mid-1980s came on the heels of a sharp increase in the relative price of U.S. goods, just as the marked improvement in the trade balance in the late 1980s coincided with a sharp decrease in relative prices (chart 5, bottom panel). Over 1997 and 1998, the real exchange value of the dollar appreciated 15 percent, and the trade deficit increased sharply

\section{Measuring the Proximate Determinants of Trade Flows}

Demand for any product is determined by, among other things, income and relative prices. In international comparisons, GDP is often considered a suitable proxy for income, and the real exchange rate is used as a measure of relative prices. These comparisons entail a great number of countries. To summarize this information, indexes are created. Because an index is one number, the weighting or aggregation scheme is particularly important.

For the trade balance (the bottom panel of chart 5), relative prices are measured by a real exchange rate index that combines a relative export price index with a relative import price index. In a U.S. export price index-an index that captures the price competitiveness of U.S. goods in foreign markets - the weight of a country's exchange-rateadjusted prices takes into account the degree to which its goods compete with U.S. goods directly in its market and indirectly in other foreign markets. For example, Germany's weight consists of the share of U.S. exports to Germany and the shares of German exports to other U.S. export markets (weighted by U.S. export shares to those markets). The weighting scheme for a U.S. import price index-an index that captures the price competitiveness of U.S. goods in the U.S. market-is more straightforward: It consists only of bilateral import shares. The broad real exchange rate, which consists of real (CPI-adjusted) exchange rates of thirty-five major U.S. trading partners, combines import and export competitiveness of U.S. goods into one measure. The weighting scheme is an average of bilateral import shares and an export weight that depends on the amount of direct exports from the United States as well as the extent to which a foreign country's exports go to third-country markets. ${ }^{1}$

For exports (middle panel of chart 5), foreign activity is measured by aggregate foreign GDP, for which the weights are each country's share in U.S. exports. Alternatively, the weighting scheme could be based on the share of each country's GDP in world GDP. However, given that the goal is to explain U.S. exports, a weighting scheme based on bilateral export shares is appropriate: This export-shareweighted measure of foreign GDP weights Mexico's GDP more heavily than its share in world GDP.

For imports (top panel of chart 5), U.S. GDP has proven to be a suitable proxy for U.S. demand, but its use is not clear-cut. Conceptually, different types of imports depend on different measures of activity. Imports that are used as intermediate inputs in the production process are determined by production, or GDP; but imports that are final consumer goods are determined by domestic demand.

1. For a complete description of the broad real index of the dollar's foreign exchange value, see Michael P. Leahy, "New Summary Measures of the Foreign Exchange Value of the Dollar," Federal Reserve Bulletin, vol. 84 (October 1998), pp. 811-18. 
5. Economic growth, real exchange rate, and trade balance, 1975-99

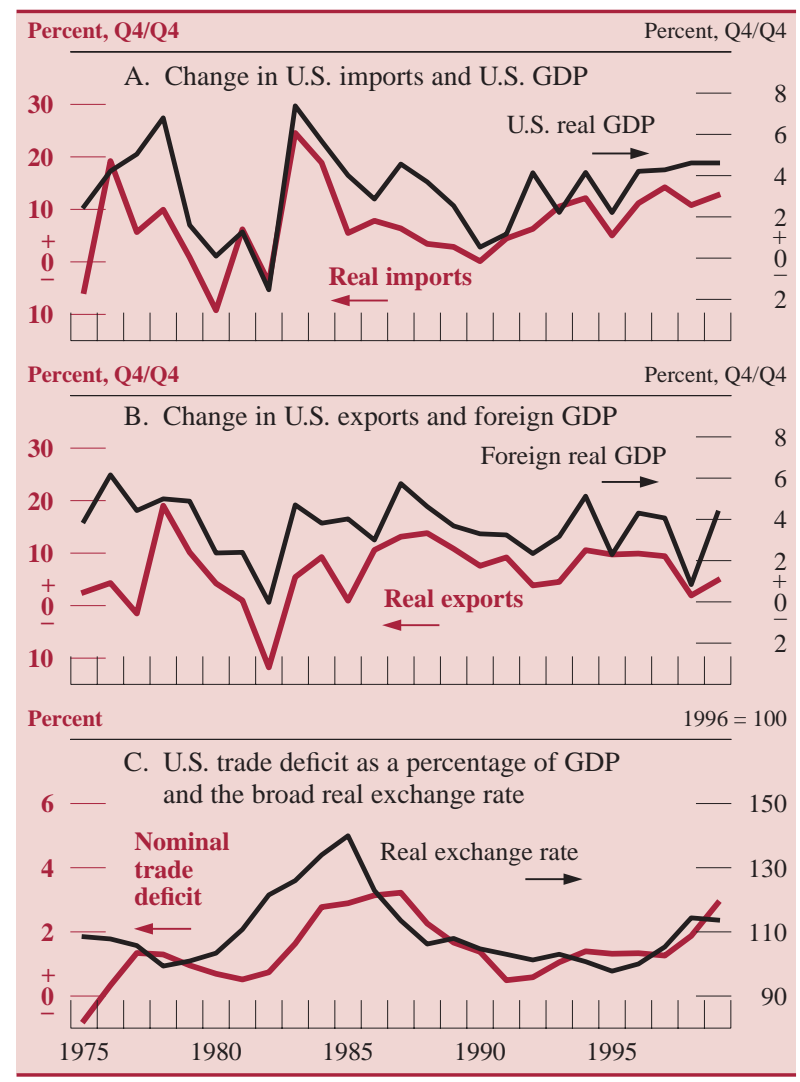

Source. U.S. Department of Commerce, Bureau of Economic Analysis, various national sources, and the Federal Reserve Board.

relative to the size of the U.S. economy. Recently, relative prices have had a more muted effect on the trade deficit, as the strong growth of the U.S. economy has dominated all other factors. However, even though U.S. price competitiveness did not deteriorate further in 1999, the lagged effects of the deterioration of the past few years-reflecting the sharp nominal appreciation of the dollar (chart 4) - continued to hold down the expansion of exports and support the expansion of imports during the year.

\section{Exports}

The value of U.S. exports of goods and services rose $\$ 26$ billion in 1999, to a level of $\$ 960$ billion, after a $\$ 5$ billion decrease in 1998 (table 3). Receipts for services rose 5 percent, after a 2 percent increase in 1998. The value of goods exports rose 2 percent, following a decline of about the same magnitude in 1998.

The value of exports of semiconductors increased 25 percent in 1999 to account for most of the overall increase in goods exports. After large increases in each of the previous three years, exports of aircraft and parts decreased slightly in 1999. The value of agricultural exports fell for the third straight year, as prices dropped 5 percent largely because of robust world supplies, particularly in world grain and oilseed markets.

In services, the increase was due mainly to enlarged receipts in three categories: "other private services," a catchall category that includes mostly business, professional, technical, and financial services; foreign travel to the United States; and freight and port expenditures by foreigners.

Exports of goods to Asian emerging markets increased $\$ 7$ billion, or about 7 percent, in 1999, after declining in 1998 (table 4). Within that total, exports to Korea in particular rose strongly. However, exports to the region remain below the levels of 1997, partly because Asian currencies are still relatively weak.

Reflecting the strength in economic activity in North America, U.S. exports to Canada and Mexico continued to advance rapidly throughout 1999. U.S. exports to Mexico expanded $\$ 8$ billion, with increases spread over all major trade categories, and over the past four years have almost doubled. The growth in exports to Canada was also strong, increasing $\$ 10$ billion, or about 6 percent; exports of automotive products accounted for almost half the increase, as cross-border shipments of automotive parts were boosted by strong vehicle sales in the United States.

In contrast to the strength of exports to Mexico, Canada, and emerging-market countries in Asia, a more mixed picture emerged for exports of goods to the rest of the world. Exports to Europe increased

4. U.S. exports of goods to its major trading partners, 1996-99

Billions of dollars

\begin{tabular}{|c|c|c|c|c|c|}
\hline Importing region & 1996 & 1997 & 1998 & 1999 & $\begin{array}{c}\text { Change, } \\
1998 \text { to } 1999\end{array}$ \\
\hline Total goods exports & 612 & 680 & 670 & 683 & 13 \\
\hline Asia & 176 & 183 & 154 & 161 & 7 \\
\hline Japan & 66 & 65 & 57 & 56 & 0 \\
\hline Other Asia ${ }^{1}$ & 110 & 118 & 97 & 104 & 7 \\
\hline Latin America & 109 & 135 & 142 & 141 & 0 \\
\hline Mexico & 57 & 71 & 78 & 87 & 8 \\
\hline Other countries & 52 & 63 & 63 & 55 & -8 \\
\hline Brazil & 12 & 16 & 15 & 13 & -2 \\
\hline Canada & 135 & 152 & 157 & 166 & 10 \\
\hline Western Europe & 138 & 153 & 159 & 162 & 3 \\
\hline All other ${ }^{2}$ & 54 & 57 & 59 & 52 & -6 \\
\hline
\end{tabular}

1. Includes China, Hong Kong, Korea, Singapore, Taiwan, Indonesia, Philippines, Malaysia, and Thailand.

2. Includes Australia, New Zealand, Middle East, Eastern Europe, and Africa. SouRCE. U.S. Department of Commerce, Bureau of Economic Analysis, U.S. international transactions accounts. 
only slightly even though economic growth had picked up in the area. Exports to Japan showed little change after falling sharply in 1998; this apparent bottoming out may be attributable to a strong yen and a steadier Japanese economy. Exports of goods to Latin America (excluding Mexico) fell sharply, and the weakness was widespread.

The quantity of exports rose almost 5 percent in 1999, more than twice as fast as in 1998 (table 5). Increases were spread across major trade categories, particularly computers, other machinery, industrial supplies, and consumer goods. In terms of composition, about 45 percent of U.S. goods exports were capital equipment, 20 percent were industrial supplies, and roughly 10 percent each were agricultural, automotive, and consumer goods.

Prices of U.S. exported goods rose $1 / 4$ percent in 1999, exhibiting the first increase in four years, notwithstanding the 5 percent drop in agricultural export prices (table 6). The turnaround in overall export prices was due largely to a 0.7 percent increase in the export prices of nonagricultural goods; a large increase in prices of exported industrial supplies more than offset continued decreases in hedonic price indexes (which are adjusted for technological change and quality improvements) for computers and semiconductors. Prices of exported services rose 2.7 percent in 1999, following a small decrease in 1998.

\section{Imports}

In 1999, the value of U.S. imports of goods and services grew $\$ 130$ billion, or 12 percent, about twice as fast as the rate in 1998 (table 3). The expansion

5. Change in the quantity of U.S. exports, 1996-99 Percent, fourth quarter to fourth quarter

\begin{tabular}{|c|c|c|c|c|}
\hline Item & 1996 & 1997 & 1998 & 1999 \\
\hline Exports of goods and services & 9.8 & 9.2 & 2.0 & 4.8 \\
\hline Services & 8.9 & 2.3 & 2.6 & 3.7 \\
\hline Goods $^{1}$ & 10.1 & 12.2 & 1.8 & 5.3 \\
\hline Agricultural products & 3.7 & 3.3 & .3 & -1.7 \\
\hline Industrial supplies ... & 6.0 & 6.3 & -2.6 & 6.4 \\
\hline Capital equipment & 15.5 & 18.2 & 4.5 & 5.8 \\
\hline Aircraft and parts & 39.9 & 10.3 & 48.8 & -16.6 \\
\hline Computers, peripherals, and parts & 21.6 & 26.1 & 7.1 & 12.0 \\
\hline Semiconductors ................ & 44.6 & 21.0 & 9.3 & 33.4 \\
\hline Other machinery and equipment & 3.4 & 17.1 & -7.9 & 6.3 \\
\hline Automotive vehicles and parts & 5.9 & 14.4 & -2.0 & 1.9 \\
\hline Consumer goods $\ldots \ldots \ldots \ldots$ & 9.8 & 7.2 & 1.2 & 5.6 \\
\hline
\end{tabular}

Note. Quantities are measured in chained (1996) dollars.

1. Selected categories are shown below.

Source. U.S. Department of Commerce, Bureau of Economic Analysis, national income and product accounts; and the Federal Reserve Board.
6. Change in prices of U.S. imports and exports of goods and services, 1996-99

Percent, fourth quarter to fourth quarter

\begin{tabular}{|c|c|c|c|c|}
\hline Item & 1996 & 1997 & 1998 & 1999 \\
\hline Total exports of goods and services & -2.1 & -.8 & -2.6 & 1.0 \\
\hline Services & 2.5 & .8 & -.4 & 2.7 \\
\hline Goods & 4.0 & -1.5 & -3.5 & .3 \\
\hline Agricultural products & -2.9 & -3.2 & -10.1 & -5.0 \\
\hline Nonagricultural goods & -4.1 & -1.3 & -3.0 & .7 \\
\hline Computers, peripherals, & -182 & -110 & -127 & 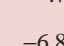 \\
\hline $\begin{array}{l}\text { and parts } \ldots . . . \cdots \\
\text { Semiconductors } \ldots . . .\end{array}$ & $\begin{array}{l}-18.2 \\
-33.1\end{array}$ & $\begin{array}{l}-11.0 \\
-13.3\end{array}$ & $\begin{array}{r}-12.1 \\
-5.6\end{array}$ & $\begin{array}{l}-0.8 \\
-3.1\end{array}$ \\
\hline $\begin{array}{l}\text { Other goods } . . . . \\
\text { MEMo }\end{array}$ & -.1 & .6 & -1.9 & 1.7 \\
\hline Industrial supplies & -2.8 & -.5 & -7.4 & 4.1 \\
\hline Total imports of goods and services & -1.8 & -4.2 & -5.0 & 3.3 \\
\hline Services & 1.8 & -2.1 & -.3 & 2.7 \\
\hline Goods .. & -2.5 & -4.6 & -5.9 & 3.4 \\
\hline Oil & 38.8 & -20.2 & -35.7 & 93.2 \\
\hline Non-oil $\ldots \ldots \ldots \ldots$ & -5.7 & -2.8 & -3.5 & -.9 \\
\hline $\begin{array}{c}\text { Computers, peripherals, } \\
\text { and parts }\end{array}$ & -15.1 & -14.8 & -16.5 & -11.3 \\
\hline Semiconductors ....... & $\begin{array}{l}-13.1 \\
-53.2\end{array}$ & $\begin{array}{l}-14.8 \\
-14.9\end{array}$ & $\begin{array}{r}-10.3 \\
-8.2\end{array}$ & -3.6 \\
\hline Other goods .... & -.7 & -.8 & -1.9 & .2 \\
\hline $\begin{array}{l}\text { MEMo } \\
\text { Industrial supnlies }\end{array}$ & -27 & -1 & -68 & 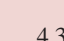 \\
\hline
\end{tabular}

SOURCE. U.S. Department of Commerce, Bureau of Economic Analysis, national income and product accounts; chain-weighted indexes; and the Federal Reserve Board.

was fueled by the sharp growth of U.S. domestic expenditures. Declines in non-oil import prices through most of the year contributed as well.

In each of the previous three years, prices of imported goods and services had fallen and thereby helped to mute inflation in the United States. In contrast, such prices, sparked by a sharp rise in the price of oil, rose 3 percent in 1999 (table 6). Non-oil import prices declined almost 1 percent over the course of the year, but there was a notable break in trend in the second half of the year; after three years of much larger price declines, a slight real depreciation of the dollar along with the turnup in primary commodity prices combined to increase non-oil import prices. The biggest shift was in imported industrial supplies, the price of which increased more than 4 percent after three years of decline.

\section{Oil Imports}

The value of U.S. oil imports increased 33 percent in 1999 (table 3) - even though the volume of oil imports changed little-because of the dramatic increase in the average price of imported oil (chart 1). The quantity of U.S. oil imports remained steady at 11.3 million barrels per day. U.S. oil consumption increased (in line with economic activity), whereas U.S. oil production decreased as a result of both increasing field maturity and depressed exploration 
and development activity following the low oil prices of 1998 and early 1999. With flat oil imports, U.S. oil inventories, which had been large at the end of 1998, were drawn down to accommodate the widened gap between domestic consumption and production.

\section{Non-Oil Imports}

The quantity of non-oil imports grew 15 percent in 1999 (table 7). An expansion in a broad range of goods was fueled by robust growth of U.S. domestic demand and was supported by declines in non-oil import prices. Reflecting the strength of spending by households and businesses in the United States, real imports of consumer goods, automotive products, computers, semiconductors, machinery, and industrial supplies advanced strongly throughout the year. The size of the increase in automotive imports in 1999 reflected buoyant automotive sales in the United States.

Payments to foreigners for services rose strongly in 1999, with increases in all service categories but especially in travel (U.S. residents traveling abroad), transportation, and other private services.

\section{Trade Policy}

Trade tensions worsened over the past two years as the strong dollar made imports relatively inexpensive, fueling competition in many industries. The steel industry was successful in gaining import protection, resulting in a reduction of steel imports by weight of 14 percent in 1999. In contrast, the robust U.S. economy, coupled with low unemployment,

7. Change in the quantity of imports, 1996-99 Percent, fourth quarter to fourth quarter

\begin{tabular}{|c|c|c|c|c|}
\hline Item & 1996 & 1997 & 1998 & 1999 \\
\hline Imports of goods and services & 11.2 & 14.2 & 10.8 & 12.6 \\
\hline Services & 5.3 & 13.6 & 8.4 & 6.9 \\
\hline Goods & 12.3 & 14.3 & 11.3 & 13.8 \\
\hline Oil . & 7.8 & 4.0 & 4.1 & -3.3 \\
\hline Non-oil ${ }^{1}$ & 12.8 & 15.2 & 11.7 & 15.2 \\
\hline Capital goods ${ }^{1}$ & 16.7 & 24.4 & 11.2 & 19.8 \\
\hline Aircraft and parts & 25.5 & 26.1 & 31.0 & -3.5 \\
\hline \multicolumn{5}{|l|}{ Computers, peripherals, } \\
\hline and parts $\ldots \ldots \ldots$ & 17.7 & 32.4 & 26.9 & 26.1 \\
\hline Semiconductors & 56.7 & 32.8 & -7.4 & 35.4 \\
\hline Industrial supplies & 11.9 & 7.3 & 8.4 & 9.0 \\
\hline Automotive products & 8.0 & 8.0 & 15.9 & 15.2 \\
\hline Consumer goods ...... & 15.1 & 14.5 & 9.4 & 15.8 \\
\hline Foods .............. & 13.5 & 9.7 & 5.4 & 11.2 \\
\hline
\end{tabular}

Note. Quantities are measured in chained (1996) dollars.

1. Selected categories are shown below.

Source. U.S. Department of Commerce, Bureau of Economic Analysis, national income and product accounts; and the Federal Reserve Board. meant that growing imports were less of a threat and did not provoke calls for restrictions in most other industries. As a result, there was no fundamental shift in U.S. trade policy, and strong imports have not, for the most part, been interpreted as damaging. Rather, they have been correctly attributed to the relative strength of the U.S. economy and credited with helping to mute inflation.

\section{DEVELOPMENTS IN THE NONTRADE CURRENT ACCOUNT}

The two major components of the current account, other than trade in goods and services, are net unilateral current transfers and net investment income.

\section{Unilateral Current Transfers}

Net unilateral current transfers include government grant and pension payments as well as net private transfers to foreigners. In 1999, the deficit on unilateral transfers increased $\$ 3$ billion, to $\$ 47$ billion (table 1). Most of the increase was in private remittances, mainly from large nonprofit institutions.

\section{Investment Income}

Net investment income is the difference between the amount that U.S. residents earn on their direct and portfolio investments abroad (receipts) and the amount that foreigners earn on their direct and portfolio investments in the United States (payments). ${ }^{4}$ Data revised in light of the results of the Benchmark Survey of U.S. Ownership of Foreign Long-Term Securities indicate that net investment income turned negative in 1998 for the first time since 1914 (table 8). Reflecting the large and persistent current account deficits over the past two decades, foreign assets in the United States have grown more rapidly than U.S. assets abroad. However, net investment income remained positive long after the net investment position became negative because foreign direct investment in the United States has earned a far lower rate of return than U.S. direct investment abroad (chart 6).

4. An investment is considered direct if a single owner or affiliated group acquires 10 percent or more of the voting equity in a company. All other U.S. claims on foreigners or foreign claims on the United States are included in the portfolio investment category. 
8. U.S. net investment income, 1995-99

Billions of dollars

\begin{tabular}{|c|c|c|c|c|c|c|}
\hline Item & 1995 & 1996 & 1997 & 1998 & 1999 & $\begin{array}{l}\text { Change, } \\
1998 \text { to } 1999\end{array}$ \\
\hline Investment income, net & 24 & 22 & 8 & -7 & -19 & -12 \\
\hline Direct investment income, net & 64 & 68 & 69 & 59 & 58 & -1 \\
\hline Receipts ................ & 96 & $\begin{array}{r}00 \\
103\end{array}$ & 116 & 103 & 117 & 14 \\
\hline Payments & 32 & 36 & 47 & 43 & 58 & 15 \\
\hline Portfolio investment income, net & -40 & -46 & -61 & -66 & -78 & -11 \\
\hline Receipts . & 114 & 120 & 141 & 154 & 155 & 2 \\
\hline Payments & 154 & 166 & 202 & 220 & 233 & 13 \\
\hline
\end{tabular}

SourCE. U.S. Department of Commerce, Bureau of Economic Analysis,

U.S. international transactions accounts.

In 1998, the net investment income balance became negative because receipts from U.S. direct investment abroad declined and the negative balance on portfolio investment increased. In 1999, a large decline in the balance on portfolio investment, coupled with a modest decrease in net direct investment income, resulted in a significant widening of the negative investment income balance.

\section{Direct Investment Income}

Net direct investment income-the difference between direct investment receipts from U.S. direct investment abroad and U.S. payments on foreign direct investment in the United States-decreased slightly in 1999, as the dollar increase in payments exceeded the increase in receipts (table 8).

Income on U.S. direct investment abroad has tended to increase with the growth of U.S. investments although it has also varied with economic conditions abroad; the decreases in receipts in 1991

6. U.S. net international investment: Position and receipts, 1980-99

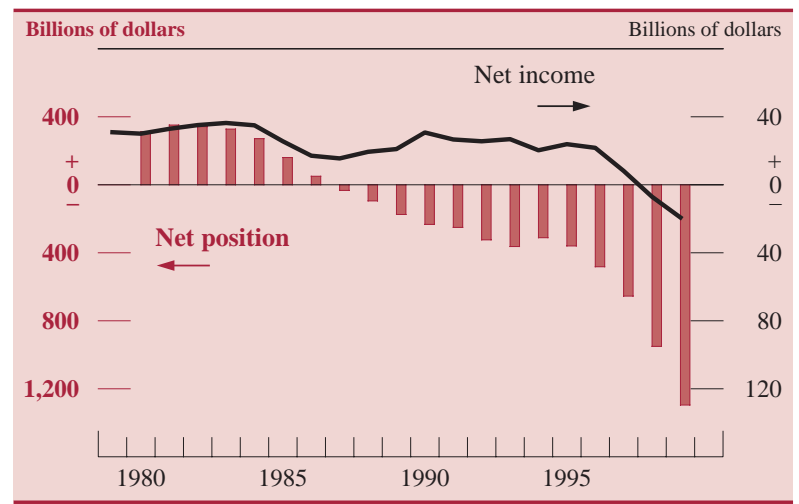

Note. The net position data are averages of the end-of-year positions for the current and previous years. The year-end position for 1999 was constructed by adding the recorded portfolio investment flows during 1999 to the recorded year-end position for 1998. The net position excludes U.S. gold holding and foreign holdings of U.S. currency.

SourCE. U.S. Department of Commerce, Bureau of Economic Analysis; and the Federal Reserve Board. and 1998, in particular, were attributable to weak economic conditions in key countries for U.S. investment (chart 7). In 1999, direct investment receipts rose sharply, to $\$ 117$ billion, because of the recovery of foreign economic growth, continued large additions to holdings by U.S. investors, and the surge in oil prices (about 10 percent of U.S. direct investment abroad is in petroleum operations).

Strong economic growth in Mexico, Canada, and Western Europe (areas that account for almost twothirds of U.S. direct investment abroad) contributed to the robust increase in receipts in 1999. The economic recovery in Asia (which accounts for slightly more than 10 percent of U.S. direct investment abroad) coincided with a strong rebound in direct investment receipts, especially from Japan, Hong Kong, and Malaysia. Receipts from Latin America, excluding Mexico, were flat; a significant downturn in profits from Brazil was offset by increases elsewhere, most notably Panama and Chile. Given the recovery of economic growth and the surge in oil

7. U.S. direct investment abroad: Position and receipts, 1980-99

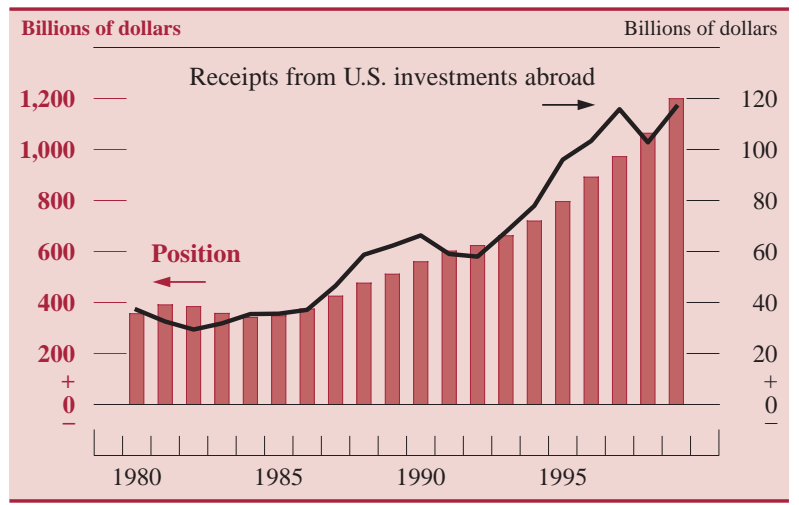

Note. The position data are averages using the current-cost measures as of year-end for the current and previous years. The year-end data for 1999 were constructed by adding the recorded direct investment capital flows and current cost adjustment during 1999 to the recorded year-end position for 1998 .

Source. U.S. Department of Commerce, Bureau of Economic Analysis; and the Federal Reserve Board. 
prices, it is surprising that the overall rate of return on U.S. direct investment abroad increased only slightly in 1999-to 9.7 percent (calculated using the receipts and position data that appear in chart 7); this figure is considerably below the 11.9 percent earned in 1997 .

Income payments on foreign direct investment in the United States, after falling in 1998, increased more than 30 percent in 1999 (table 8). Direct investment payments have not always kept pace with the growth of foreign direct investment in the United States; in the 1980s the direct investment position increased substantially, but payments showed no upward trend (chart 8). Since the early 1990s, payments have increased smartly, in line with the increased profitability of U.S. corporations. The robust increase in 1999 resulted from both the bright profits picture for the U.S. economy and the massive acquisitions undertaken by foreign direct investors in 1998 and again in 1999. The overall rate of return on a current cost basis rose significantly, from 5.3 percent to 5.7 percent, but is still well below both the 1997 return of almost 6.5 percent and the current return on U.S. direct investment abroad.

The balance on direct investment income remains positive because of the positive net direct investment position and the large differential in the rates of return on U.S. direct investment abroad and foreign direct investment in the United States. While the reasons for the differential in the rates of return are not well understood, age-related factors appear to be important: Foreign direct investment in the United States is typically newer than U.S. direct investment abroad and is hence more likely to be incurring startup and restructuring costs and less likely to have

8. Foreign direct investment in the United States: Position and payments, 1980-99

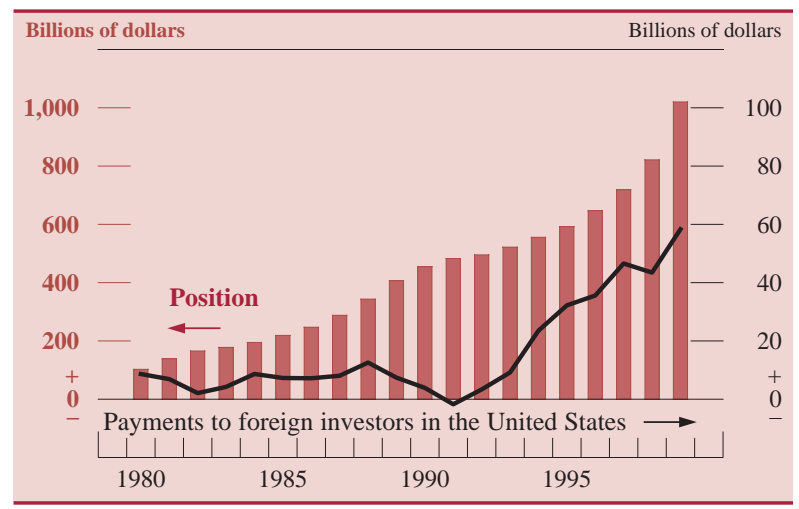

NotE. The position data are averages using the current-cost measures as of year-end for the current and previous years. The year-end data for 1999 were constructed by adding the recorded direct investment capital flows and currentcost adjustment during 1999 to the recorded year-end position for 1998 .

SourCE. U.S. Department of Commerce, Bureau of Economic Analysis; and the Federal Reserve Board.
9. Net portfolio investment: Position and income, 1980-99

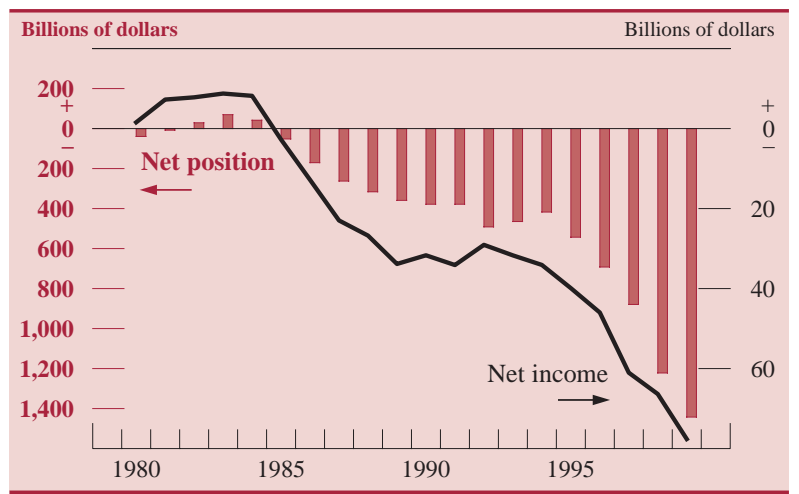

Note. The net position data are averages of the end-of-year net positions for the current and previous years. The year-end position for 1999 was constructed by adding the recorded portfolio investment flows during 1999 to the recorded year-end position for 1998

SourcE. U.S. Department of Commerce, Bureau of Economic Analysis; and the Federal Reserve Board.

reaped the benefits of experience. However, last year, as in 1998, the positive balance on net direct investment income did not offset the negative balance on net portfolio investment income.

\section{Portfolio Investment Income}

Portfolio investment income consists of dividends and interest paid on a wide range of claims and liabilities. Receipts and payments are estimated by the Bureau of Economic Analysis (BEA) of the Department of Commerce based on estimates of holdings, dividend-payout ratios, and interest rates. Investment income does not include capital gains associated with changes in securities prices. The balance on portfolio income has been in deficit since 1985, and its size has broadly mirrored the net portfolio investment position (chart 9).

In 1998, net payments did not grow nearly so fast as the net liability position because interest rates fell and rapidly rising equity prices in the United States increased the value of foreign holdings of U.S. equities without a commensurate increase in dividend payments. This can be seen by the narrowing gap between the bars (the position) and the line (net income) in chart 9. In 1999, a further decline in interest rates and an increase in equity prices again damped the increase in net payments relative to the deterioration of the net position.

\section{The 1997 Benchmark Survey of U.S. Ownership of Foreign Long-Term Securities}

The data on net portfolio investment income were recently revised to take into account the newly avail- 
9. U.S. holdings of foreign long-term securities, by country of issuer, December 31, 1997 Billions of U.S. dollars except as noted

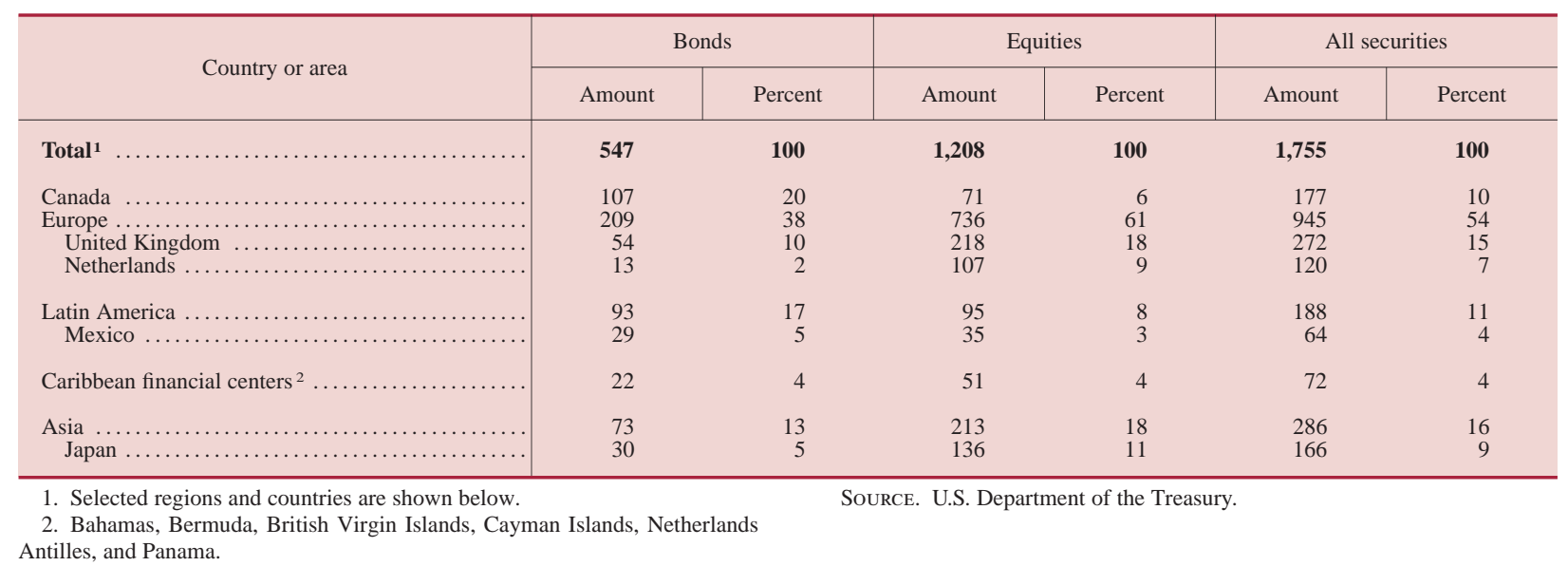

able results of the Treasury Department's Benchmark Survey of U.S. Ownership of Foreign Long-Term Securities, conducted as of year-end 1997. The previous benchmark survey had been conducted as of March 1994.

A comparison of the two benchmark surveys indicates that, between surveys, official statistics significantly underestimated U.S. portfolio holdings of foreign equities and long-term debt instruments (those with original maturities greater than one year). The 1997 survey measured U.S. holdings of foreign securities 21 percent higher than predicted by the 1994 survey and subsequent transactions data adjusted for prices and exchange rates. ${ }^{5}$ Based on preliminary results from the 1997 survey, BEA increased its estimate of U.S. holdings of foreign assets, thereby increasing its estimate of U.S. investment income earned abroad and reducing the estimated deficit in the balance of payments accounts. Further adjustments will be made this year with the release of final data.

The benchmark survey offers a snapshot of U.S. holdings of foreign securities at year-end 1997. At that time, U.S. holdings of foreign long-term securities totaled $\$ 1,755$ billion (table 9). U.S. holdings were widespread-fifty-four countries attracted at least $\$ 1$ billion in U.S. investment-but relatively concentrated, with 67 percent of total investment occurring in ten countries. The United Kingdom, with some $\$ 272$ billion in U.S. investment, was the

5. The data on U.S. international capital flows are collected regularly by the Treasury International Capital (or TIC) Reporting System; they cover only transactions (that is, purchases and sales of securities), not holdings. Between benchmark surveys of U.S. holdings of foreign securities, which have occurred in 1943, 1994, and 1997, BEA uses the TIC transactions data, along with estimates of price and exchange rate changes, to estimate holdings. country of choice for U.S. investors, followed by Canada, Japan, the Netherlands, and Germany. U.S. investors held considerably more foreign equities than foreign debt securities, with $\$ 1,208$ billion invested in equities and $\$ 547$ billion in debt. The Treasury Department estimates that, until 1987, U.S. investors held more foreign debt securities than foreign equities.

The survey showed that U.S. holdings of foreign securities doubled between March 1994 and December 1997. Many studies find that net purchases of foreign equity in a particular market are positively related to the expected equity returns in that marketthat is, local market conditions matter. Information asymmetries likely also matter, however, as a closer look at the types of foreign equities that U.S. investors are holding reveals. When investing directly in a foreign market, U.S. investors must glean information produced by accounting practices that may differ from general U.S. accounting practices. However, foreign stocks that are listed on U.S. exchanges, either directly or as exchange-traded American Depositary Receipts (ADRs), must conform to general U.S. accounting practices, thereby reducing the information costs to the U.S. investor. ${ }^{6}$ In fact, U.S. investors seem to prefer foreign equities that trade on U.S. exchanges: About 30 percent of the foreign equities held by U.S. investors trade on U.S. exchanges. Moreover, the fact that shares of Dutch companies make up many of the largest exchangetraded ADR programs helps to explain the apparent

6. ADRs, specifically marketed to U.S. investors, are receipts for shares of stock in foreign companies that are held in a custodial account by or for a U.S. bank. These receipts are then traded on U.S. securities exchanges in U.S. dollars. ADRs entitle the owners to all dividends, capital gains or losses, and voting rights just as if they directly owned the underlying shares. 
10. Composition of U.S. capital flows, 1995-99

Billions of dollars

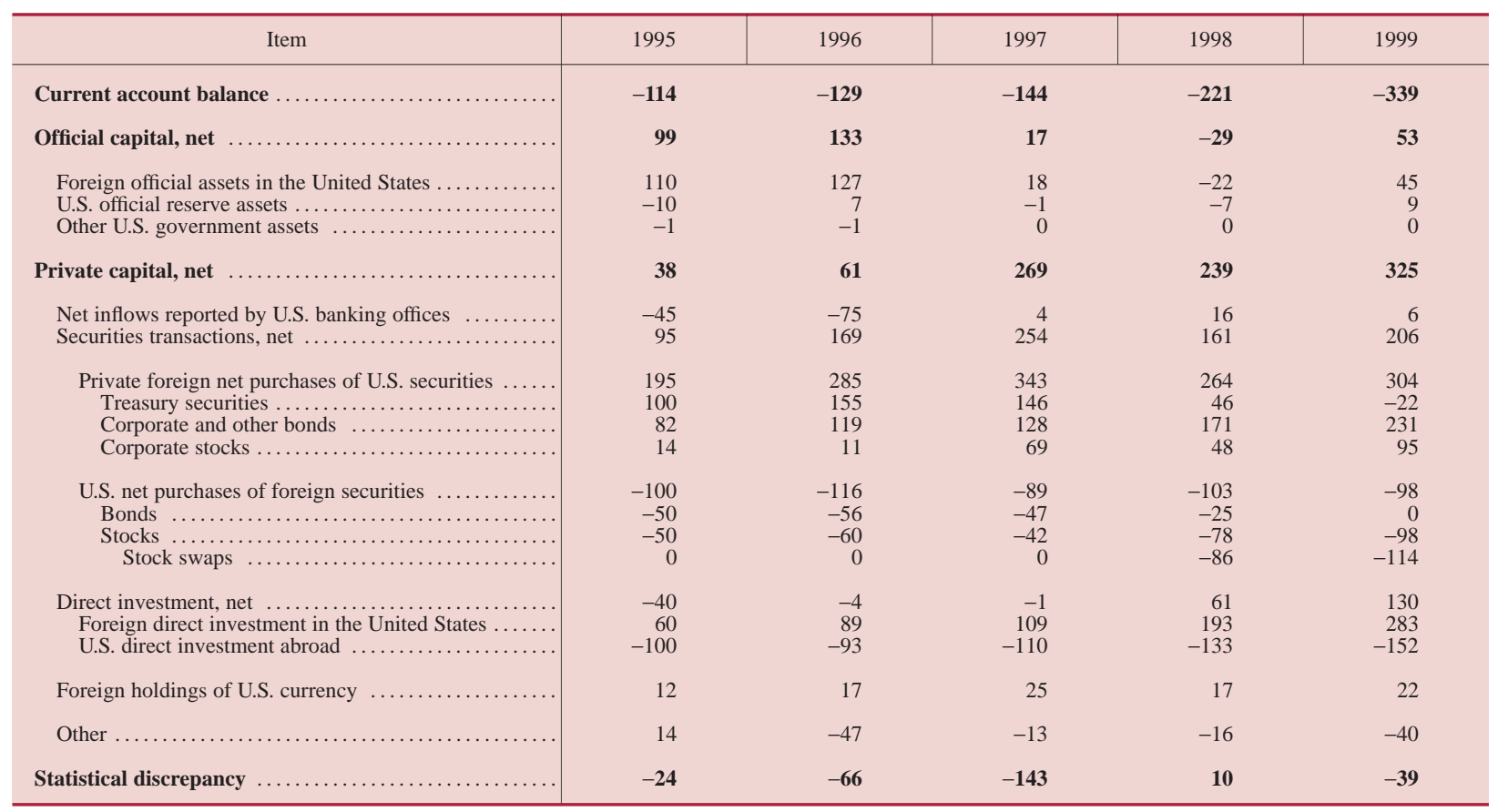

SouRCE. U.S. Department of Commerce, Bureau of Economic Analysis, U.S. international transactions accounts.

overweighting of Dutch stocks in U.S. portfolios. Dutch stocks make up 9 percent of U.S. investors' foreign equities portfolios but less than 4 percent of the market capitalization outside the United States.

In U.S. investors' foreign debt portfolios, 58 percent of the foreign debt is dollar-denominated. While U.S. investors seek the higher returns of foreign debt, generally they try to avoid direct currency risk, although in doing so they are subject to increased credit risk.

\section{FINANCIAL AND CAPITAL ACCOUNT TRANSACTIONS}

As described in footnote 1 , the capital account has recently been redefined. It now consists mainly of debt forgiveness and transfers of goods and financial assets by migrants as they enter or leave the country. Transactions in the new capital account are quite small in the U.S. data (table 1) but are much larger for some developing countries.

The new financial account, previously termed the capital account, consists of private and official capital flows. In time, these may come to be called financial flows, but in general they are still referred to as capital flows.
U.S. capital flows in 1999 reflected the relatively strong cyclical position of the U.S. economy and the global wave of corporate mergers. Net private capital inflows reached $\$ 325$ billion in 1999, a sharp acceleration from their robust pace of 1998, to exceed the record total set in 1997 (table 10). The faster pace was due mainly to record capital inflows; capital outflows, both direct and portfolio, remained at their high levels of the past few years.

Net foreign purchases of U.S. securities were strong in 1999, reaching \$304 billion. Underneath the near-record amount lay a significant shift in the composition. U.S. budget surpluses reduced the supply of U.S. Treasury securities, and government-sponsored enterprises such as Fannie Mae and Freddie Mac, as well as some large U.S. corporations, strove to fill the void by issuing "benchmark" or "reference" debt that mimics many of the attributes of Treasury securities. Private foreigners on net sold $\$ 22$ billion in U.S. Treasury securities in 1999, the first year of foreign net sales since 1990. These were more than offset by a pickup in foreign purchases of their nearest substitutes - agency bonds and corporate bonds. Foreign purchases of agency bonds reached $\$ 74$ billion in 1999, and foreign purchases of corporate bonds reached $\$ 158$ billion; purchases of both types of bonds were significantly higher than the previous 
record levels recorded in 1998. Private foreign purchases of U.S. stocks also reached record levels (\$95 billion) in 1999.

Foreign direct investment flows into the United States were also extremely robust in 1999, easily surpassing the record inflow set in 1998. As in 1998, direct investment inflows were elevated by several large mergers, the largest of which was the Vodafone AirTouch deal. These mergers left their imprint on other parts of the capital account as well. In the past two years, many of the largest mergers have been financed by swapping equity in the foreign acquiring firm - which has usually been European-for equity in the U.S. firm that is being acquired. The BEA estimates that, through this mechanism, U.S. residents acquired \$114 billion of foreign equity in 1999 . It is likely that to rebalance their portfolios, U.S. investors subsequently sold a significant portion of the equity acquired through stock swaps. On net, U.S. residents acquired large amounts of Japanese and European equities in 1999.

U.S. residents made modest net purchases of foreign bonds in 1999. U.S. direct investment flows abroad also reflected the global wave of merger activity in 1999 and exceeded their record level of 1998.

Net official capital inflows picked up in 1999, reaching \$53 billion, a marked increase over 1997 and 1998 but far below the record level of \$133 billion set in 1996. Foreign official assets in the United States increased $\$ 45$ billion after a moderate decline in 1998. The 1998 decline in foreign official assets in the United States was fairly widespread, as many countries found their currencies under unwanted downward pressure during the turmoil. In contrast, the increase in foreign official reserves in the United States in 1999 was fairly concentrated, as a relatively few countries experienced unwanted upward pressure on their currencies vis-à-vis the U.S. dollar. In particular, increases in Japanese reserves in the United States, which were associated with intervention in the foreign exchange market, more than accounted for the overall increase in 1999.

With net recorded capital inflows to the United States exceeding the large current account deficit in 1999, the U.S. international accounts recorded a negative statistical discrepancy, after a small positive discrepancy in 1998 and an extremely large negative one in 1997. A negative discrepancy indicates that net payments in the current account or net outflows in the financial account have been unrecorded. For example, illegal drug imports would contribute to a negative discrepancy, as would unrecorded investments abroad by U.S. residents or overstated investments in the United States by foreigners. Inadequacies in the data on trade in services also confound the international accounts, although the effect on the discrepancy is not clear. Given the severity of the swings in the discrepancy over the past few years, the negative discrepancy in 1999 was likely caused by overstated capital inflows.

\section{PROSPECTS FOR 2000}

Domestic spending may well continue to outstrip domestic production and increase the current account deficit. But adjustments that should slow the process are also at work. If recovery in foreign economies stays on course, U.S. exports should continue to expand. The sharp appreciation of the dollar in 1997 and 1998 should have a diminished effect on U.S. trade; without further dollar appreciation, the price competitiveness of U.S. goods should improve, a change that would tend to reduce the deficit. Net investment income is likely, however, to continue to increase the current account deficit, as the large excess of foreign assets in the United States above U.S. assets abroad implies that foreign investors should continue to earn more in the United States than U.S. investors earn in other countries. 